\title{
Algal pigments in Hornsund (Svalbard) sediments as biomarkers of Arctic productivity and environmental conditions
}

\author{
Magdalena KRAJEWSKA*, Małgorzata SZYMCZAK-ŻYŁA \\ and Grażyna KOWALEWSKA \\ Marine Pollution Laboratory, Institute of Oceanology, Polish Academy of Sciences, \\ Powstańców Warszawy 55, 81-712 Sopot, Poland \\ * corresponding author <mkrajewska@iopan.gda.pl>
}

\begin{abstract}
Pigments (chloropigments-a and carotenoids) in sediments and macroalgae samples, collected in Hornsund, in July 2015 and July 2016, were analysed (HPLC) in this work. In spite of the aerobic conditions and the periodic intensive solar irradiation in the Arctic environment, neither of which favour pigment preservation in water column and surface sediments, our results indicate that these compounds can provide information about phytoplankton composition, primary production and environmental conditions in this region. The sum of chloropigments-a, a marker of primary production, in the Hornsund sediments varied from 0.40 to $14.97 \mathrm{nmol} / \mathrm{g} \mathrm{d}$.w., while the sum of carotenoids ranged from 0.58 to $8.08 \mathrm{nmol} / \mathrm{g}$ d.w. Pheophorbides-a and pyropheophorbides-a made up the highest percentage in the sum of chloropigments-a in these sediments, supplying evidence for intensive zooplankton and/or zoobenthos grazing. Among the carotenoids, fucoxanthin and its derivatives (19'-hexanoyloxyfucoxanthin and 19'-hexanoyloxy-4-ketofucoxanthin) contributed the highest percentage, which points to the occurrence mainly of diatoms and/or haptophytes in the water. The pigment markers show that the input of macroalgae to the total biomass could be considerable only in the intertidal zone.
\end{abstract}

Key words: Arctic, Spitsbergen, pigments, sediments, HPLC.

\section{Introduction}

Pigments (chloropigments and carotenoids) are natural compounds widespread in aquatic environments. They occur mainly in phytoplankton, macroalgae and bacteria but also, together with their derivatives, in detritus sinking through the water and settling on the seabed (Jeffrey et al. 1997). As a result, sediments may contain a large variety of pigments. The sediment pigments are universal markers of productivity, phytoplankton taxonomy and environmental conditions 
in the adjacent water (Louda et al. 2002; Bianchi et al. 2002; Fietz et al. 2007; Freiberg et al. 2011; Szymczak-Żyła et al. 2011). The sum of chloropigments-a, like $\beta$-carotene, is an indicator of primary production (Schüller et al. 2013; Szymczak-Żyła et al. 2017), while specific chlorophyll-a derivatives are markers of environmental conditions (Szymczak-Żyła et al. 2011). As pigments may be degraded to their derivatives by both abiotic and biotic factors, i.e. by light, heat, oxygen, herbivore grazing or microorganism activity, these compounds provide information about conditions in the water column and sediments (Welschmeyer and Lorenzen 1985; Bianchi et al. 1988; Louda et al. 1998, 2002; Szymczak-Żyła et al. 2006). Carotenoids together with chlorophylls-c and chlorophyll-b are markers of the main phytoplankton groups (Jeffrey and Vesk 1997).

Pigment records in sediments are the averaged indicators of what has happened over a period of time in a basin (Meyers 1997). Pigments in sediments give an information about changes in past algae blooms, sources of organic matter, ecosystem productivity and environmental, preservation conditions (Meyers 1997; Kowalewska et al. 1999). The great advantage of studying pigments in sediments in order to gauge the average annual situation is that samples can be collected $e . g$., once a year or less often. This is in contrast to water, which has to be sampled frequently, since pigment concentrations in water are variable in time and space (Szymczak-Żyła and Kowalewska 2007; Dobrzyn et al. 2009). Hence, the analysis of pigments in sediments helps to understand the trends of processes taking place in an environment.

It is known that only about $10 \%$ of total productivity leaves the euphotic zone and is transported to sediments (Tribovillard et al. 2006). It has been estimated as well that c. $10 \%$ of chlorophyll-a produced in water is transferred to the sediments of the Gulf of Gdansk, which is an eutrophic area (Szymczak-Żyła and Kowalewska 2007). The majority of chlorophyll-a is degraded in water column and in uppermost sediment layer to colourless product (Reuss et al. 2005). The concentrations of pigments in sediments can be interpreted on the basis of primary production, its sources and environmental conditions in study area, e.g., photo-chemical oxidation, organisms grazing or oxygen concentration.

There are numerous papers concerning pigments in the sediments of lakes, open seas, shelf areas and estuaries (e.g., Leavitt et al. 1997; Chen et al. 2001; Reuss et al. 2005; Szymczak-Żyła and Kowalewska 2007; Canuel et al. 2009; Tani et al. 2009; McGowan et al. 2012 and references therein). However, only a few authors have studied these compounds in Arctic regions. Spitsbergen fjords could be interesting areas for studying pigments so long as these are not decomposed to colourless products under conditions unfavourable to pigment preservation. Contemporary global warming has advanced, and its effects are more apparent in Arctic than in mid latitudes (Manabe and Stouffer 1980; Morata and Renaud 2008; Węsławski et al. 2010; Kay et al. 2012; Gervais et al. 2016); environmental conditions in high latitudes have been greatly influenced as a result (Overpeck $e t$ 
al. 1997; Post et al. 2009; Wassmann et al. 2011). The large inflow of freshwater from glacier melting lowers water salinity and increases turbidity, which may in turn affect phytoplankton composition (Wiktor and Wojciechowska 2005). The usual approach of microscopically identifying the phytoplankton composition in Arctic regions, also in the Hornsund fjord (Wiktor and Wojciechowska 2005; Piwosz et al. 2009) is time consuming and costly (Paerl et al. 2003). Most of the few papers on pigments in Arctic aquatic environments relate to seawater (Dobrzyn et al. 2009; Pettersen et al. 2011) or lacustrine sediments (Guillizzoni et al. 2006; Anderson et al. 2008; Jiang et al. 2011; Florian et al. 2015); those authors detected chloropigments predominantly by fluorometry, not HPLC. The latter method enables the qualitative and quantitative analysis of pigments and their derivatives (Jeffrey and Wright 1997; Morata and Renaud 2008).

The aim of this work was to find out whether algal pigments in the Arctic fjord sediments could be used as biomarkers for these marine environments relating to productivity, phytoplankton composition, sources of organic matter and environmental changes. The fieldwork was carried out in Hornsund, one of the Spitsbergen fjords, which is being impacted by changing environmental conditions and is one of the most thoroughly explored by scientific expeditions.

\section{Study area}

Hornsund, a cold-water fjord (mean depth $90 \mathrm{~m}$, max. depth $260 \mathrm{~m}$ ) on the western side of the southernmost tip of Spitsbergen, is connected with the Greenland Sea (Fig. 1). During summer, Hornsund may be under the influence of warm Atlantic waters (West Spitsbergen Current) or cold Arctic waters (Sørkapp Current) (Swerpel 1985). Hornsund is characterized by different water masses between $-1.5^{\circ} \mathrm{C}$ and $3^{\circ} \mathrm{C}$ in temperature, and from 34 to 35 in salinity (Cottier et al. 2005). The water in the vicinity of the glaciers is stratified as a result of glacial melting and freshwater inflows to the fjord, but there is no stratification nearer the fjord mouth (Swerpel 1985). The volume of freshwater in Hornsund in summer is about $0.79 \mathrm{~km}^{3}$, but only $40-50 \%$ of this water enters the fjord as glacier melt water. The remaining freshwater comes from Arctic Water transported by the East Spitsbergen Current (Beszczyńska-Möller et al. 1997). Hornsund has the highest oxygen uptake in sediments of several fjords along Spitsbergen's west coast (Jørgensen et al. 2005). The sediment accumulation rate may be as fast as $35 \mathrm{~cm} /$ year in the inner part of Hornsund (Brepollen) but only $0.1 \mathrm{~cm} /$ year in the outer part (Görlich et al. 1987). In the central basin, glacier melting processes release mainly mineral and some organic particles to fjord water and are responsible for high sedimentation rate in this area $(\sim 1 \mathrm{~cm} / \mathrm{yr})$. High water turbidity reduces the euphotic zone to $5-10 \mathrm{~m}$ and as a result primary production is limited there (Wróbel et al. 2013). In outer part of the fjord, sedimentation 
rates are lower $(\sim 0.1 \mathrm{~cm} / \mathrm{yr})$, the euphotic zone - deeper $(20-55 \mathrm{~m})$ and primary production - higher (Görlich et al. 1987; Wróbel et al. 2013). The dominant sediments, mostly silt, in Hornsund are very fine-grained and rather homogeneous (Grzelak and Kotwicki 2012; Drewnik et al. 2016). The organic carbon content was estimated from 0.8 to $1.8 \%$ (Drewnik et al. 2016).

\section{Materials and methods}

Sample collection. - Sediments were sampled at seven stations in Hornsund (Fig. 1). The sediments at stations H1 , H2, H3 were collected in July 2015, those at stations H4, H5, H6, H7 in July 2016. The sampling sites were selected in such a way as to cover a wide range of environmental conditions in the study area, i.e. different water depth, salinity, dissolved oxygen levels and distance from the coastline and glaciers. Station $\mathrm{H} 1$ was located in the eastern part of Burgerbukta, $\mathrm{H} 7$ at the entrance to Burgerbukta, $\mathrm{H} 2$ and $\mathrm{H} 6$ in Brepollen, the innermost part of Hornsund, and H3 in Isbjørnhamna, near the Polish Polar Station. Station H5 was situated in the central part of the fjord - this was the deepest of the stations. Station H4 was situated in the outer part of Hornsund. The stations were characterized by differences in salinity, temperature and oxygen concentration in the near-bottom water (Table 1). Salinity varied between 33.3 (station $\mathrm{H} 3$ ) and 35.4 (station $\mathrm{H} 6$ ). Near-bottom temperatures ranged from $-1.1^{\circ} \mathrm{C}$ (H2) to $4.2^{\circ} \mathrm{C}(\mathrm{H} 6)$, and oxygen concentrations between $11.03 \mathrm{mg} / \mathrm{l}(\mathrm{H} 5)$ and

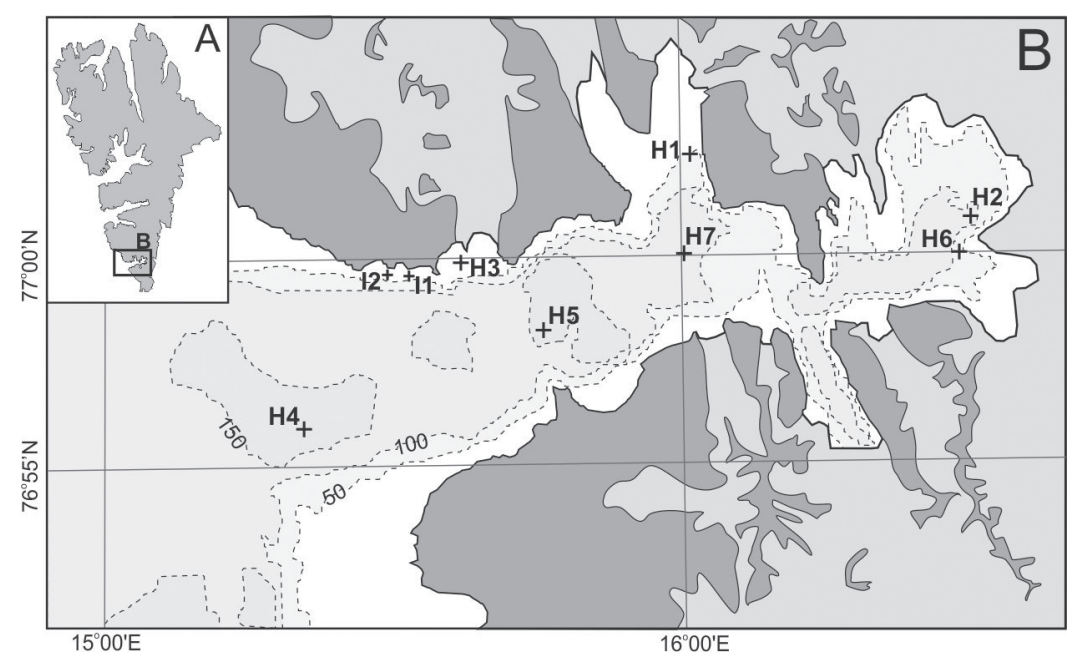

Fig. 1. Map of Spitsbergen (A) and bathymetric map of the Hornsund fjord (B) with location of the sampling sites. Glaciers are shown in light grey, while land areas without glaciers are shown in dark grey. 
Table 1

Characteristics of the sampling stations.

\begin{tabular}{|c|c|c|c|c|c|c|}
\hline \multirow[b]{2}{*}{ Station } & \multirow[b]{2}{*}{ Coordinates } & \multirow{2}{*}{$\begin{array}{l}\text { Collection } \\
\text { date }\end{array}$} & \multirow{2}{*}{$\begin{array}{l}\text { Water depth } \\
{[\mathrm{m}]}\end{array}$} & \multicolumn{3}{|c|}{ Parameters of near-bottom water* } \\
\hline & & & & salinity & $\begin{array}{l}\text { temp. } \\
{\left[{ }^{\circ} \mathrm{C}\right]}\end{array}$ & $\begin{array}{c}\text { oxygen } \\
{[\mathrm{mg} / \mathrm{l}]}\end{array}$ \\
\hline H1 & $\begin{array}{l}77^{\circ} 02.373^{\prime} \mathrm{N} \\
16^{\circ} 01.473^{\prime} \mathrm{E}\end{array}$ & July 2015 & 71 & 34.5 & 1.6 & 14.78 \\
\hline $\mathrm{H} 2$ & $\begin{array}{l}77^{\circ} 01.358^{\prime} \mathrm{N} \\
16^{\circ} 32.041^{\prime} \mathrm{E}\end{array}$ & July 2015 & 92 & 35.1 & -1.1 & 12.52 \\
\hline H3 & $\begin{array}{l}77^{\circ} 00.570^{\prime} \mathrm{N} \\
15^{\circ} 37.319^{\prime} \mathrm{E}\end{array}$ & July 2015 & 50 & 33.3 & 3.5 & 13.39 \\
\hline $\mathrm{H} 4$ & $\begin{array}{l}76^{\circ} 56.098^{\prime} \mathrm{N} \\
15^{\circ} 21.059^{\prime} \mathrm{E}\end{array}$ & July 2016 & 134 & 33.8 & 2.2 & 12.00 \\
\hline H5 & $\begin{array}{l}76^{\circ} 58.953^{\prime} \mathrm{N} \\
15^{\circ} 45.821^{\prime} \mathrm{E}\end{array}$ & July 2016 & 228 & 34.8 & 3.0 & 11.03 \\
\hline H6 & $\begin{array}{l}77^{\circ} 00.5911^{\prime} \mathrm{N} \\
16^{\circ} 29.2633^{\prime} \mathrm{E}\end{array}$ & July 2016 & 165 & 35.4 & 4.2 & 11.55 \\
\hline $\mathrm{H} 7$ & $\begin{array}{l}77^{\circ} 00.696^{\prime} \mathrm{N} \\
16^{\circ} 00.929^{\prime} \mathrm{E}\end{array}$ & July 2016 & 107 & 35.0 & 3.5 & 12.00 \\
\hline
\end{tabular}

*measured with a ProfiLine Multi 197i WTW meter

$14.78 \mathrm{mg} / \mathrm{l}(\mathrm{H} 1)$. The sediments were obtained with a GEMAX twin-core sampler during cruises of r/v Oceania. The cores were sliced into intervals of $0-1,1-5$, 5-10, 10-15 and 15-20 cm and frozen on board immediately after collection. Surface sediment samples $(0-1 \mathrm{~cm})$ were also taken at two locations in the intertidal zone (stations I1 and I2) in July 2015. Macroalgae (Laminaria digitata, Desmaresta aculeata, Fucus sp., Acrosiphonia sp.) were collected along the coast of the fjord in the intertidal zone, near the River Revelva, in July 2015. All the samples were stored at $-20^{\circ} \mathrm{C}$ until analysis. The salinity, temperature and oxygen concentration were measured with an SBE19 probe (vertical profiles in the water column) and with a ProfiLine Multi 197i WTW meter (near-bottom water).

Pigment analysis. - Pigments were extracted from the sediment samples according to the procedure used by the Marine Pollution Laboratory of the Institute of Oceanology, Polish Academy of Sciences (Szymczak-Żyła and Kowalewska 2009). A frozen sediment sample $(0.5-10 \mathrm{~g})$ was placed in a glass centrifuge tube and left to thaw. Water was removed by centrifugation (6 min, $2500 \mathrm{rpm}$ ). Samples were mixed with acetone, sonicated (2-3 min), centrifuged again and the 
extract decanted. The extraction was repeated until the supernatant was colourless (max. three times). The pooled acetone extracts were transferred to a separating funnel for liquid-liquid extraction in the acetone extract:benzene:water system $(15: 1: 10 \mathrm{v} / \mathrm{v} / \mathrm{v})$. The benzene layer was transferred to a glass vial, evaporated to dryness in a stream of argon, and stored frozen $\left(-20^{\circ} \mathrm{C}\right)$ until HPLC analysis. The extracted sediment was dried at $60^{\circ} \mathrm{C}$ and weighed. The pigment content was calculated per dry sediment weight $(\mathrm{nmol} / \mathrm{g})$.

Acetone was added to the frozen macroalgae, which were then crushed with a glass rod. The samples were centrifuged (6 min, $2500 \mathrm{rpm}$ ) and injected into the HPLC system. Pigments in macroalgae were determined only qualitatively in order to identify the pigment composition.

Samples dissolved in acetone were injected into a Lichrospher column 100RP-

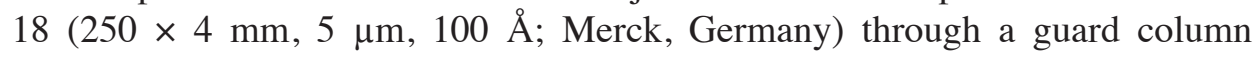
(Lichrospher 100RP-18 endcapped, $4 \mathrm{~mm} \times 4 \mathrm{~mm}$; Merck, Germany) using an HPLC-DAD system (Knauer, Germany). The HPLC system consisted of an autosampler (Optimas), three pumps (Smartline 100), a degasser (Smartline), column thermostat (Smartline) and detector (DAD-K-2800). Different gradient systems were used for separating chloropigments and carotenoids.

Chloropigments-a, chlorophyll-b and pheophytin-b were separated using a two-solvent (A - acetone, B - 80:20 acetone:water v/v) gradient system, at a flow rate of $1.00 \mathrm{ml} / \mathrm{min}$. The mobile phase and gradient system was according to that in Szymczak-Żyła et al. (2008). The chromatograms were recorded at $660 \mathrm{~nm}$ and $650 \mathrm{~nm}$.

Chlorophylls-c were analysed using an HPLC system (Knauer, Germany) equipped with a fluorescence detector (FL, RF-20Axs, Shimadzu, Japan). The analysis was carried out in the same two-solvent (A - acetone, B - 80:20 acetone: water $\mathrm{v} / \mathrm{v}$ ) gradient system at a flow rate of $0.5 \mathrm{ml} / \mathrm{min}$. The excitation and emission wavelengths were 440 and $630 \mathrm{~nm}$, respectively. The chlorophylls-c contents were obtained according to the procedure described by Kowalewska et al. (1996).

Carotenoid separations were carried out using a mobile phase consisting of three solvents ( $\mathrm{A}-85: 15$ methanol: 0.5 M ammonium acetate, aq. v/v, B - 90:10 acetonitrile: water $\mathrm{v} / \mathrm{v}, \mathrm{C}$ - ethyl acetate) in a gradient system and a flow rate of $1.00 \mathrm{ml} / \mathrm{min}$. The mobile phase/gradient system was described in Krajewska et al. (2017). The chromatograms were recorded at $450 \mathrm{~nm}$.

Absorption spectra were measured over the $360-750 \mathrm{~nm}$ range. The solvents (HPLC grade, VWR International Sp. z o.o.) were filtered and degassed with helium before analysis. Identification of individual pigments was based on the retention times, and absorbance spectra were compared with individual pigment standards (DHI, Denmark). Pigments were quantified according to the method given in Kowalewska et al. (1996) and Krajewska et al. (2017). 
Statistical analysis. - The results were statistically processed using STATISTICA 12.5 software (StatSoft, Poland). Principal component analysis (PCA) was applied with the standardization of chlorophylls-c, chlorophyll-b and additional parameters.

Results and interpretation

Pigment distribution and primary production. - The pigment concentrations in different sediment layers at the fjord stations $(\mathrm{H} 1-\mathrm{H} 7)$ and in the surface sediment layer at stations I1 and I2 in the intertidal zone are shown in Fig. 2. The sum of chloropigments-a $(\Sigma$ Chlns-a) in the fjord sediments
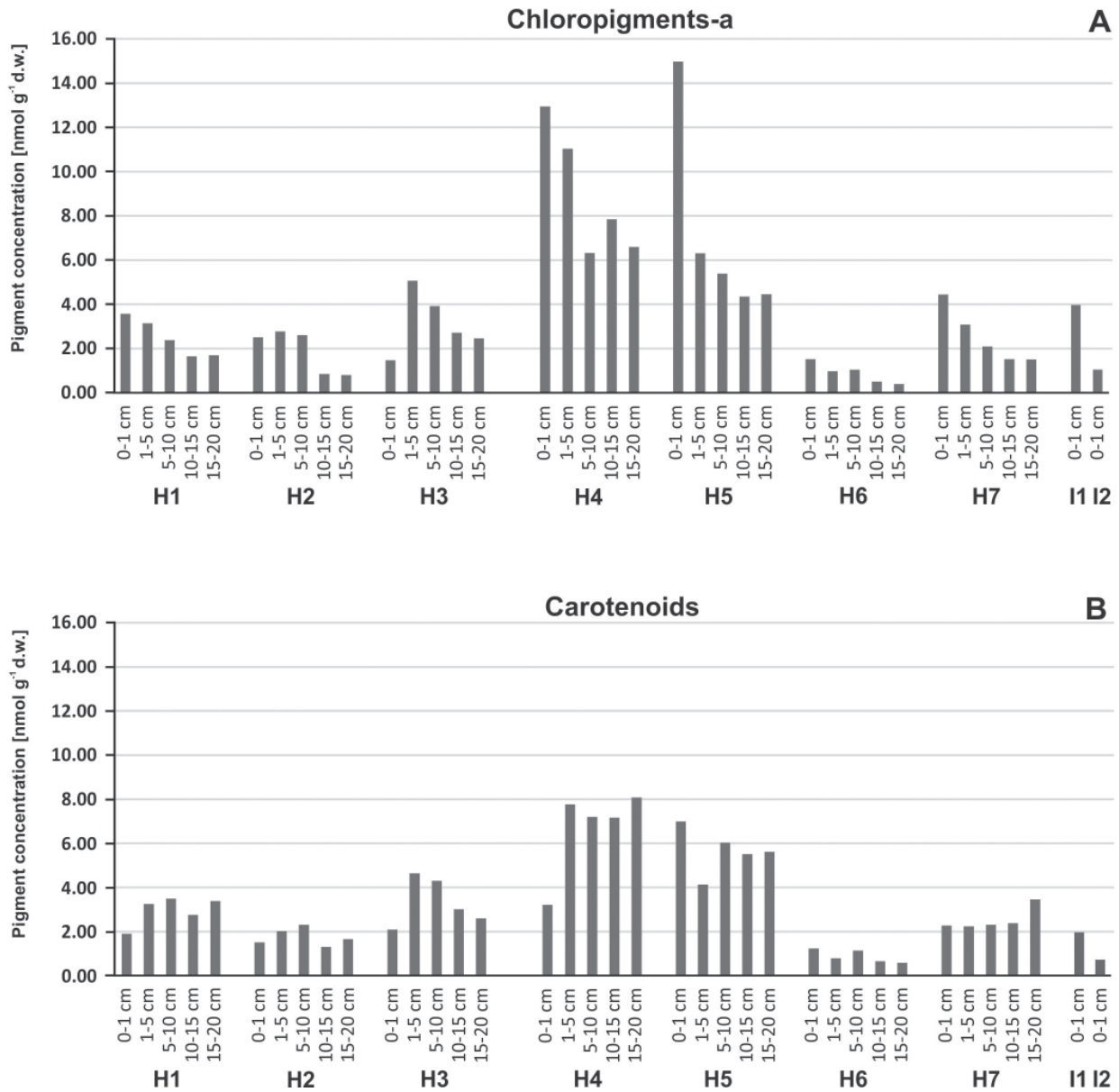

Fig. 2. Contents of the sum of (A) chloropigments-a and (B) carotenoids. 
(H1-H7) varied from 0.4 (station $\mathrm{H} 6,15-20 \mathrm{~cm}$ ) to $14.97 \mathrm{nmol} / \mathrm{g} \mathrm{d.w}$. (station $\mathrm{H} 5,0-1 \mathrm{~cm}$ ), whereas total carotenoids ranged from 0.58 (station $\mathrm{H} 6,15-20 \mathrm{~cm}$ ) to $8.08 \mathrm{nmol} / \mathrm{g}$ d.w. (station $\mathrm{H} 4,15-20 \mathrm{~cm}$ ). Despite the aerobic conditions in the near-bottom water (Table 1) and the potentially intensive solar irradiation in summer, which can speed up pigment degradation in water column, considerable amounts of pigments are transferred to Hornsund sediments and preserved. Although the concentrations are not high, they are comparable with values obtained for other coastal areas of different latitudes where aerobic conditions also prevailed, e.g., coastal areas of the Gdansk Basin, the Pomeranian Bay, the Venice Lagoon, and the coasts of Scotland (Szymczak-Żyła and Kowalewska 2007; Szymczak-Żyła et al. 2011), Trondheimsfjord (Cibic et al. 2007) and India (Rasiq et al. 2016).

The highest concentrations of chloropigments-a and carotenoids were determined in sediments in the outer part of the fjord (H4, H5) (Fig. 2). The high pigment concentration in these areas might have resulted from a higher level of primary production, which increases from the inner to the outer fjord (from 14.00 to $86.65 \mathrm{mg} \mathrm{C} \mathrm{m}^{-2} \mathrm{~h}^{-1}$ ) (Piwosz et al. 2009) or from low accumulation of mineral particles (Zaborska 2017; Zaborska et al. 2017). However, the percentage of undecomposed chlorophyll-a in the surface sediments $(0-1 \mathrm{~cm})$ was from $0.5 \%$ (H5) to $23 \%$ (H3) (Fig. 3). Such a low percentage of chlorophyll-a additionally confirms that $\Sigma$ Chlns-a is a better marker of primary production than the commonly used chlorophyll-a (Szymczak-Żyła et al. 2017).

Environmental conditions. - Pheophorbides-a and pyropheophorbides-a made up the highest percentage among chlorophyll-a derivatives in the sediments at all fjord stations except H3 (Isbjørnhamna) (Fig. 3). Pheophorbides-a are relatively less stable derivatives of chlorophyll-a and indicate the presence of fresh organic matter. Pyropheophorbides-a are markers of zooplankton and/ or zoobenthos grazing (Szymczak-Żyła et al. 2011). The high percentage of pyropheophorbides-a in the $0-1 \mathrm{~cm}$ layer of the Hornsund sediments at the stations in Burgerbukta and Brepollen (H1, H2, H6 and H7) indicates that chlorophyll-a decomposes there mainly as a result of biotic factors, i.e. zooplankton/zoobenthos grazing.

Based on results of ${ }^{210} \mathrm{~Pb}$ analysis (Zaborska 2017; Zaborska et al. 2017, in press), we can suppose that there was no sediment mixing at stations in Burgerbukta (H1), entrance to Burgerbukta (H7), at one station in Brepollen (H6) and in outer part of fjord $(\mathrm{H} 4, \mathrm{H} 5)$, which is in agreement with the decreasing profile of $\Sigma$ Chlns-a (Fig. 2) in sediments and there was a slight mixing at stations $\mathrm{H} 2$ and $\mathrm{H} 3$. At stations $\mathrm{H} 1, \mathrm{H} 7$ and $\mathrm{H} 6$, the high percentage of pyropheophorbides-a suggests intensive zooplankton activity. The majority of zooplankton in Hornsund consists of herbivorous species (Piwosz et al. 2009): the copepod Calanus glacialis, known to be a key phytoplankton grazer in the 


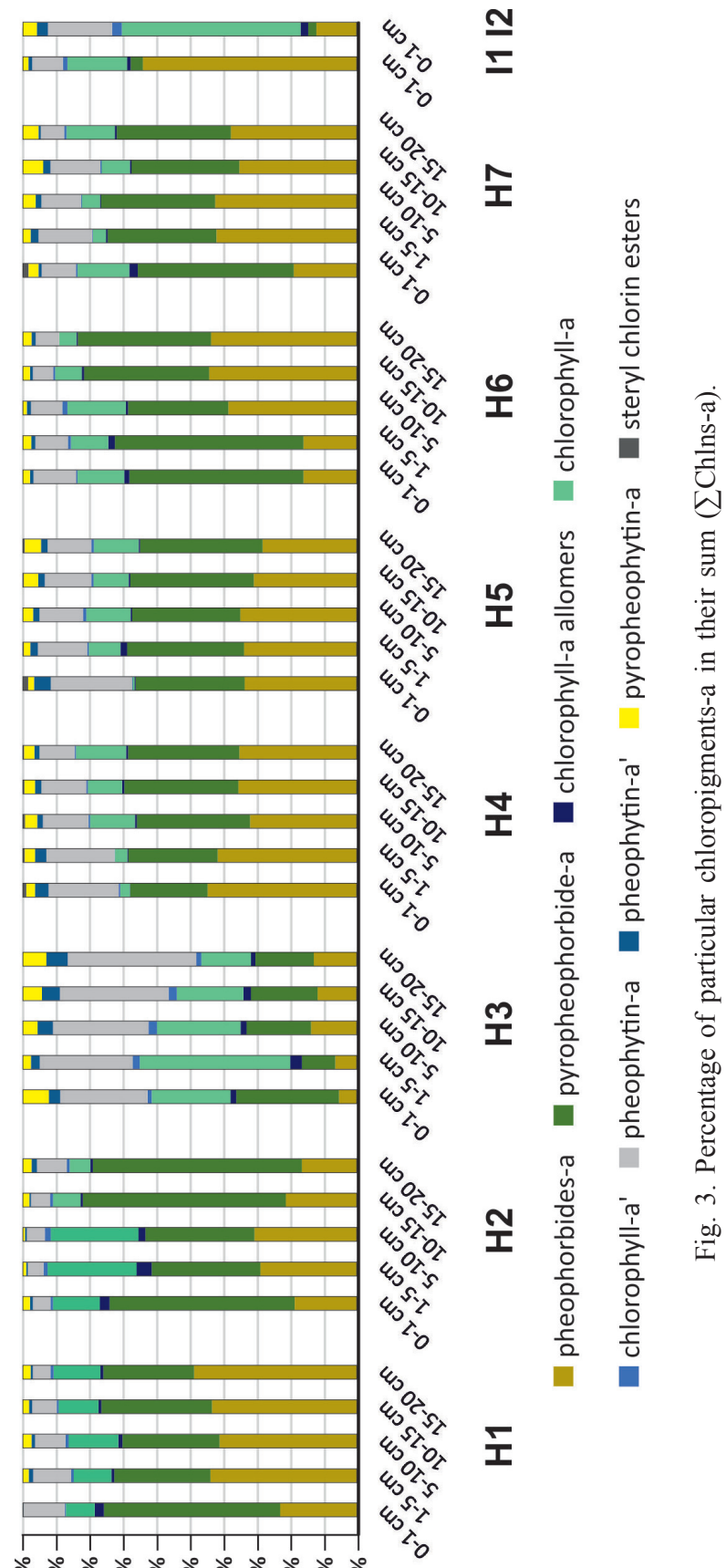

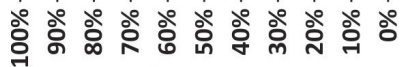


Arctic, is a major contributor to the Hornsund zooplankton (Weydmann et al. 2016). The slight mixing $(\sim 3 \mathrm{~cm})$ at station H2, stated by Zaborska 2017 , is confirmed by our results, i.e. the higher concentration of $\Sigma$ Chlns-a in deeper than in surface sediment layer. The high percentage of pyropheophorbides-a at station $\mathrm{H} 2$ suggests that benthic activity is responsible for sediment mixing at this site, which tallies with the information that mixing in the surface sediment layers of Hornsund is caused mainly by bioturbation (Zajączkowski et al. 2010; Włodarska-Kowalczuk et al. 2013).

The situation at station H3 (Isbjørnhamna) is different. The sediments there contained more undecomposed chlorophyll-a (Fig. 3), i.e. up to $45 \%$ in the $1-5 \mathrm{~cm}$ sediment layer. At this station (H3), the percentage of pheophytin-a, the marker of senescent/slightly decomposed phototrophic matter in sediments, was also high $(\sim 30 \%)$, indicating that another set of factors was influencing organic matter decomposition. At $\mathrm{H} 3$, the sediment was probably mixed $(\sim 2 \mathrm{~cm})$ (Zaborska 2017), but contained a smaller percentage of pyropheophorbides-a than sediments from the stations in Burgerbukta and Brepollen (H1, H2, H6 and $\mathrm{H} 7$ ). This suggests that slight mixing at station $\mathrm{H} 3$ may be caused by abiotic factors, e.g., currents or activity of glaciers. Station H3 was situated near the Hansbreen glacier, so mixing was most likely due to glacier recession. In addition, the small amount of pyropheophorbides-a (a marker of grazing) is linked with the high mortality of zooplankton communities resulting from freshwater outflow from the glacier (Węsławski and Legeżyńska 1998). A high percentage of fucoxanthin, a marker of diatoms, was also recorded at station H3 (Fig. 4). Fucoxanthin contains an epoxy group and is regarded as an unstable carotenoid (Itoh et al. 2003; Patoine and Leavitt 2006), as it is highly degraded in sediments (Reuss and Conley 2005). Consequently, the high levels of fucoxanthin and undecomposed chlorophyll-a in the sediments at station $\mathrm{H} 3$ indicate that fresh organic matter was present there. Indeed, the $20 \mathrm{~cm}$ long core at this station was formed during about 23 years (Zaborska 2017).

The large amounts of pigments at the outer-fjord stations (H4, H5) suggest that conditions there were favourable for pigment preservation in sediments. Station H5 is the deepest one and the oxygen concentration was the lowest of all such values measured in near-bottom water (Table 1). The surface sediment layers $(0-1 \mathrm{~cm})$ at stations $\mathrm{H} 4$ and $\mathrm{H} 5$ contained a high percentage of pheophorbides-a and pheophytin-a, but very small amounts of chlorophyll-a. These sediments differ from those collected at station H3 (Isbjørnhamna) in the percentage of chlorophyll-a and pheophorbides-a, but have a similar pheophytin-a percentage. Based on the accumulation rate, we can estimate that the $0-1 \mathrm{~cm}$ layer was formed during about 1 year (H3), 4 years (H5) (Zaborska 2017) and 6 years (H4) (Zaborska et al. 2017). The same surface sediment layer at the outer stations ( $\mathrm{H} 4$ and $\mathrm{H} 5$ ) was formed during a longer period of time than at station $\mathrm{H} 3$, which could have caused the decomposition of chlorophyll-a to pheophorbides-a. 


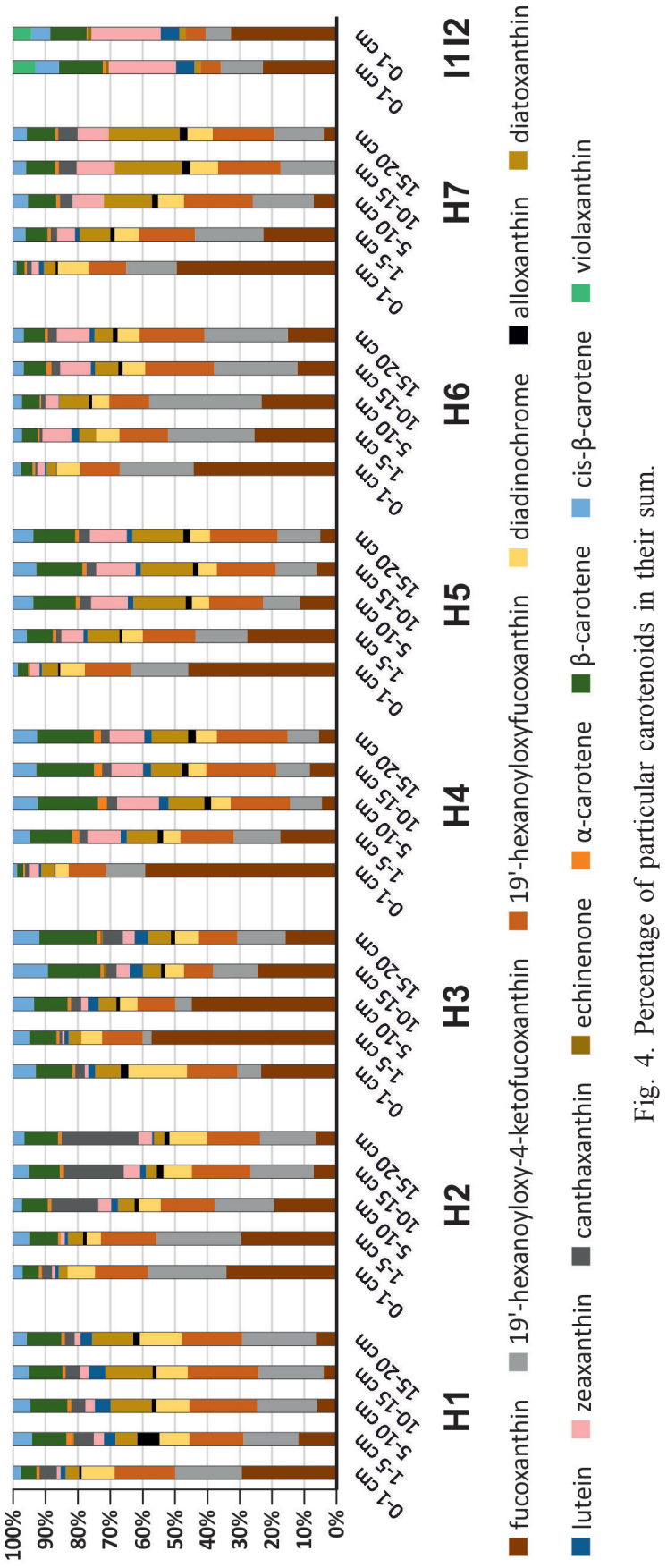


At stations $\mathrm{H} 4$ and $\mathrm{H} 5$ grazing was also less intensive than at stations $\mathrm{H} 2$, H6 (Brepollen) and H1, H7 (Burgerbukta, entrance to Burgerbukta), which is in agreement with the information that the percentage of herbivorous zooplankton increased from the outer to the inner part of Hornsund (Piwosz et al. 2009).

Taking into account the percentage of the most abundant chloropigments-a, carotenoids and standardized parameters, i.e. concentrations of chlorophylls-c and chlorophyll-b, as well as additional parameters (station depths, accumulation rates, near-bottom water parameters - salinity, temperature, oxygen concentration) for the Hornsund stations $(\mathrm{H} 1-\mathrm{H} 7)$, the results of the statistical analysis show that the stations divide into 4 groups (Fig. 5). This confirms our earlier conclusions, e.g., regarding the exceptionally high amount of undecomposed chlorophyll-a at station H3. The stations in Burgerbukta and Brepollen ( $\mathrm{H} 1, \mathrm{H} 2, \mathrm{H} 6$ and $\mathrm{H} 7)$ have a high percentage of pyropheophorbides-a and differ from $\mathrm{H} 4$ and $\mathrm{H} 5$ in the concentrations of chlorophylls-c and chlorophyll-b. Stations H1, H2 differ from H6, H7, for example, in the percentage of fucoxanthin derivatives.

Recent sediments $(0-1 \mathrm{~cm})$ were also collected in the intertidal zone (Fig. 1). They differed in the percentages of chlorophyll-a and pheophorbides-a (Fig. 3), but both contained fresh material, because pheophorbides-a are the initial products of chlorophyll-a decomposition under good oxygen conditions.

Phytoplankton taxonomy. - Carotenoid concentrations in sediments give an idea of which phytoplankton species are present. At each station $(\mathrm{H} 1-\mathrm{H} 7)$, fucoxanthin and its derivatives (19'-hexanoyloxyfucoxanthin, 19'-hexanoyloxy4-ketofucoxanthin) were the predominant carotenoids in the sediments (Fig. 4). Analysis of the first $0-1 \mathrm{~cm}$ layer $(\mathrm{H} 1, \mathrm{H} 4-\mathrm{H} 7)$ and the carotenoid level in the 0-1 $\mathrm{cm}$ and 1-5 cm layers at stations $\mathrm{H} 2$ and $\mathrm{H} 3$ (averaged due to sediment mixing) indicates that the sum of 19'-hexanoyloxyfucoxanthin and 19'-hexanoyloxy-4ketofucoxanthin in the sediments at stations H1 (Burgerbukta) and H2 (Brepollen) made up a higher percentage than of fucoxanthin. This is indicative of the presence of haptophytes, since fucoxanthin, 19'-hexanoyloxyfucoxanthin and 19'-hexanoyloxy-4-ketofucoxanthin are haptophyte carotenoid markers (Zapata et al. 2004). Wiktor and Wojciechowska (2005) determined haptophytes (Phaeocystis puchetii, Chrysochromulina sp.) in water from Hornsund.

The percentage of fucoxanthin was higher at stations $\mathrm{H} 3-\mathrm{H} 7$ than that of its derivatives, suggesting that diatoms were the predominant species there. The occurrence of diatoms is also confirmed by the presence of diatoxanthin and diadinochrome in the sediments. Diadinoxanthin, a diatom marker, is an unstable carotenoid, diadinoxanthin is ranked 3 on a four-point scale: 1-most stable, 4-least stable (Leavitt and Hodgson 2001), and was not recorded in the sediments. Instead, diadinochrome was found. Diadinochrome is a rearrangement product of diadinoxanthin, which can occur in some diatoms (Borodina and Ladygina 2013). 

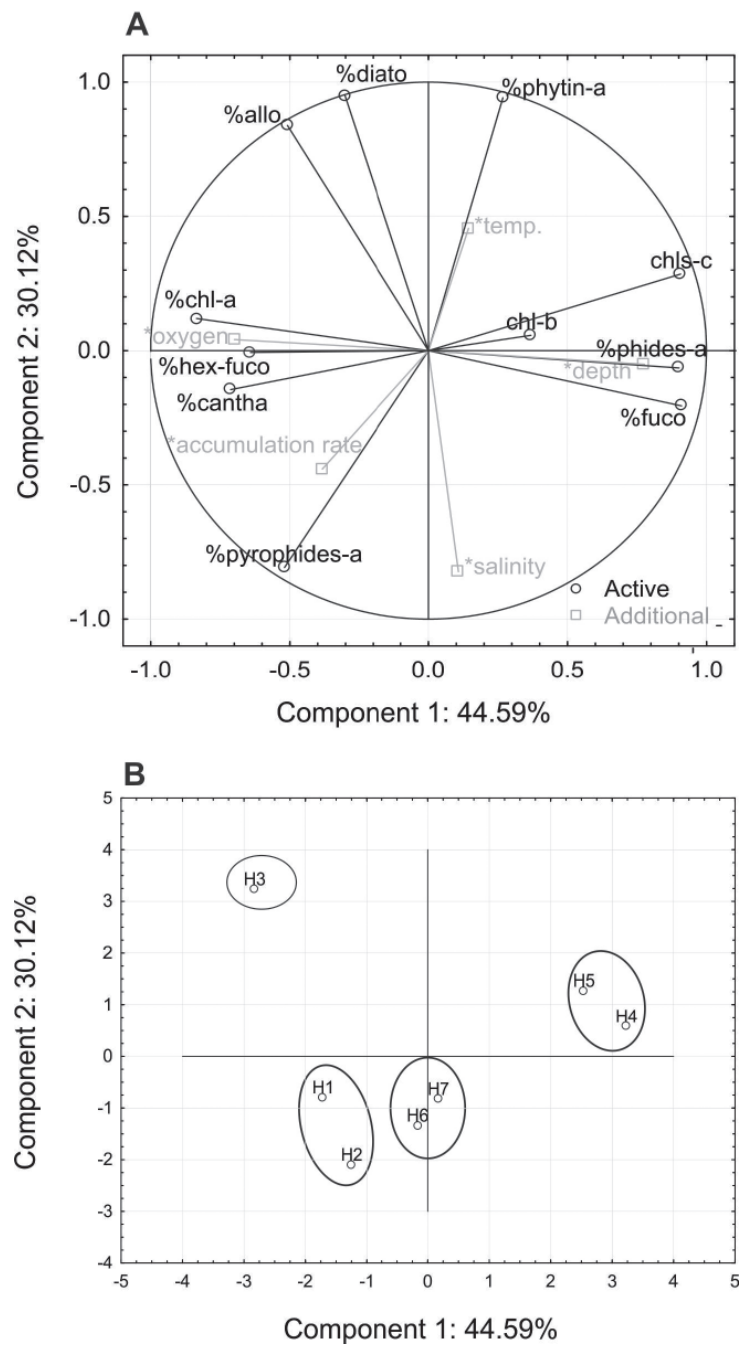

Fig. 5. Results of the statistical analysis: (A) scatter plot of principal component loading by individual variables; (B) scatter plot of principal component object scores by sampling sites, based on characteristic of the surface $(0-1 \mathrm{~cm})$ sediment layer: the percentage of main carotenoids and chloropigments-a, concentration of chlorophyll-b, concentration of chlorophylls-c and as additional parameters: accumulation rates and near-bottom water parameters (salinity, temperature and oxygen concentrations).

Diatoxanthin is more often determined in sediments than diadinoxanthin, because in sediments the latter decomposes rapidly to the former (Reuss et al. 2005).

At stations $\mathrm{H} 1$ and $\mathrm{H} 2$, by contrast, intensive zooplankton grazing might have reduced the abundance of diatoms, the major food item of Calanus spp. (Falk-Petersen et al. 2002, 2009; Wold et al. 2011), so most of the carotenoids 
at $\mathrm{H} 1$ and $\mathrm{H} 2$ derived from nanoplankton, like haptophytes, have been preserved in the sediments.

There was also a high percentage of fucoxanthin at the stations in Brepollen (H6) and at the entrance to Burgerbukta (H7), despite the high level of pheophorbides-a. The considerable fucoxanthin content at station H6 implies that accumulation rate was higher there $(\sim 0.66 \mathrm{~cm} / \mathrm{yr})$ than at $\mathrm{H} 4(\sim 0.17 \mathrm{~cm} / \mathrm{yr})$ and H5 ( $\sim 0.23 \mathrm{~cm} / \mathrm{yr})$ (Zaborska 2017; Zaborska et al. 2017) and that fucoxanthin was not completely decomposed in the water. At station $\mathrm{H} 7$, the accumulation rate $(0.23 \mathrm{~cm} / \mathrm{yr}$, Zaborska et al. in press) was not so high as at $\mathrm{H} 6$, but despite intensity of zooplankton grazing, primary production of diatoms was also evidently higher.

According to Piwosz et al. (2009), diatoms made up the majority of the total biomass in the whole of Hornsund. It was observed that diatoms were present when cold water flows in from the Barents Sea (Wiktor and Wojciechowska 2005). This is in agreement with our results. The concentration of chlorophylls-c, a diatom marker, was higher at stations close to the entrance to Hornsund (H4, H5) than in its inner part (Fig. 6). In Arctic environment, diatoms can originate mainly from pelagic or ice blooms (Leu et al. 2015), however organic carbon produced by sea ice autotrophs constitute only from 1 to $12.5 \%$ of total primary production in this region (Arrigo et al. 2008). Ice algal blooms are often dominated by diatoms, which are the first food sources for sympagic, pelagic and benthic herbivores, after long winter time (Leu et al. 2015). Actually, there are no available observation of ice flora in Hornsund. Newetherless, it is known that due to small ice cover in the fjord, especially in recent years in connection with contemporary global warming, ice-associated algae biomass is low (Wiktor and Wojciechowska 2005; Smoła et al. 2017). Observations conducted by Muckenhuber et al. (2016), in years 2000-2014, show that maximum fast ice cover, i.e. sea ice attached to the coastline, exceed about $40 \%$ of the fjord area in all studied years, except for 2012 and 2014, when ice season was shorter and the maximum ice cover stayed below 20\%. The other potential source of ice diatoms can be ice transported from Barents Sea with the Sørkapp Current (Hegseth 1992; Wiktor and Wojciechowska 2005).

Fucoxanthin may origin also from nanoflagellates, like haptophytes, and these taxa were observed as dominant at some water depths in Hornsund (Piwosz et al. 2005). However, these organisms are difficult to identify under the microscope due to their small size and delicate structures (Wiktor and Wojciechowska 2005), while our pigment analysis indicated that they may make up a large proportion of the biomass in Hornsund. Thus, pigment analysis in sediments can facilitate the identification of phytoplankton in this area.

A high percentage of canthaxanthin (almost $24 \%$ of the sum of all carotenoids identified) was recorded in the $15-20 \mathrm{~cm}$ sediment layer at $\mathrm{H} 2$ (Fig. 4). Canthaxanthin is a marker of the nitrogen-fixing cyanobacteria of the order 


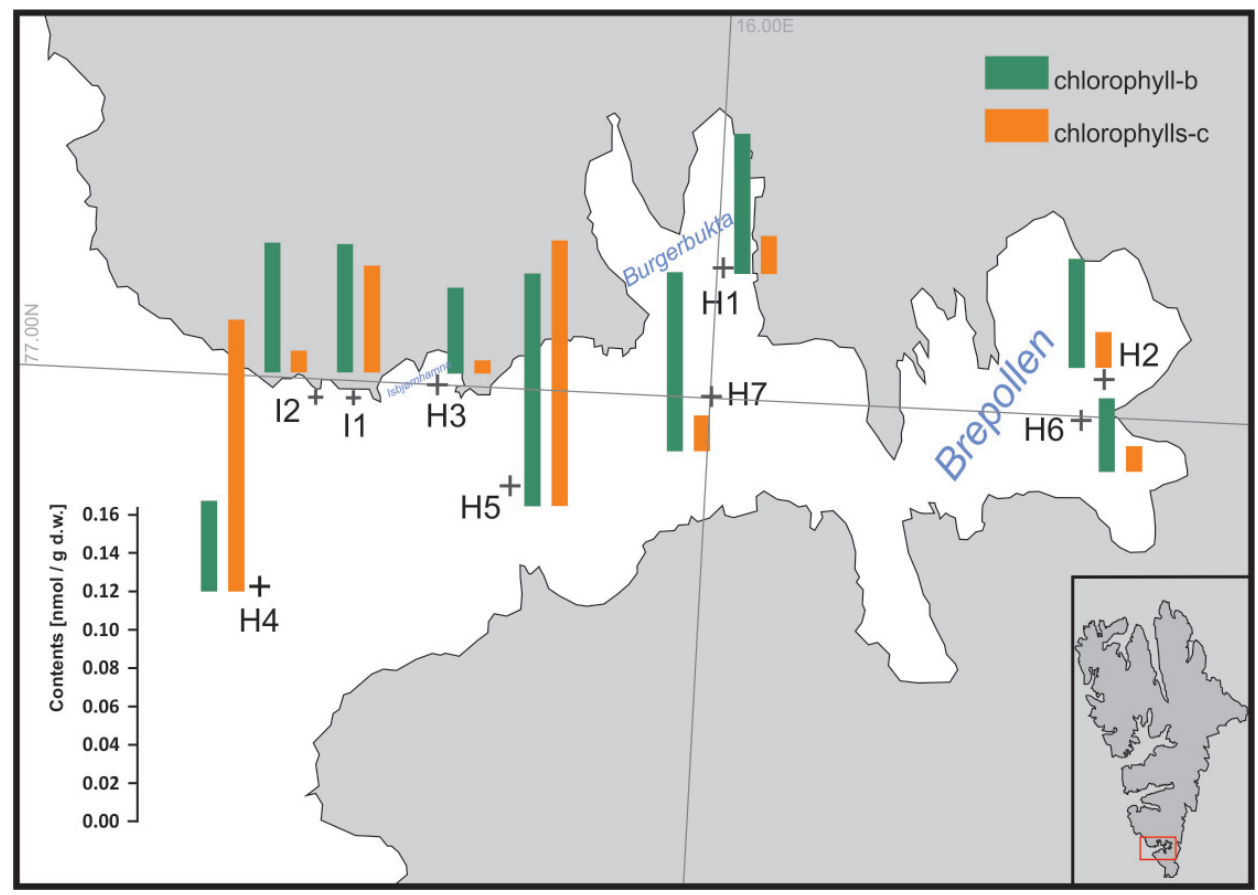

Fig. 6. Contents of chlorophyll-b and chlorophylls-c in $0-1 \mathrm{~cm}$ sediment layer.

Nostocales (Desphande et al. 2014). In polar environments, cyanobacteria are a major source of nitrogen, as they can fix this gas from the air (Chapin et al. 1991; Birkemoe and Liengen 2000; Stewart et al. 2011).

Sources of organic matter. - The most abundant pigments in the macroalgae samples (Laminaria digitata, Desmaresta aculeata, Fucus sp.) were chlorophylls-c, chlorophyll-a, fucoxanthin, violaxanthin, antheraxanthin, zeaxanthin and $\beta$-carotene. The presence of zeaxanthin, violaxanthin and antheraxanthin show that one of the xanthophyll cycles has taken place in macroalgae, a process protecting photoautotrophs against photooxidation (Louda et al.2002). In addition to the above-mentioned pigments, lutein and chlorophyll-b were detected in Acrosiphonia sp., a green algae.

Recent sediments $(0-1 \mathrm{~cm})$ from the intertidal zone (I1, I2) contained from 0.6 to $1.6 \mathrm{nmol} / \mathrm{g}$ of carotenoids (Fig. 2). Besides fucoxanthin and its derivatives, these sediments also contained violaxanthin and more zeaxanthin (Fig. 4) than the sediments from the fjord (H1-H7). This suggests an input from macroalgae, which contain these latter two pigments. The pigments in the intertidal zone sediments probably originated from macroalgae, in contrast to the sediments from the fjord stations $(\mathrm{H} 1-\mathrm{H} 7)$, where the organic matter originated mainly from 
phytoplankton (diatoms, haptophytes), as described in the previous section. The higher ratio of chlorophyll-b to chlorophylls-c (Fig. 6), at stations closer to the Hornsund shoreline ( $\mathrm{H} 1-\mathrm{H} 3, \mathrm{H} 6, \mathrm{H} 7)$, suggests that some of this organic matter may have terrigenous origin, because glacier melt water contains chlorophyll-b (Aliani et al. 2003).

\section{Conclusions}

The main results can be summarized as follows:

- the sum of chloropigments-a ( $\sum$ Chlns-a) is a better marker of primary production in Hornsund than chlorophyll-a,

- macroalgae may be the main source of organic matter only for sediments in the intertidal zone; the organic matter in Hornsund was derived mainly from phytoplankton,

- diatoms and haptophytes constitute the majority of the plant biomass in Hornsund,

- zooplankton grazing is the main factor decomposing organic matter in Hornsund.

Acknowledgements. - This work was partially financed from the funds of the Leading National Research Centre (KNOW) obtained by the Centre for Polar Studies for the period 2014-2018, and partly within the framework of grant No. 2016/21/N/ ST10/03240 from the National Science Centre, Poland. We extend our gratitude to Agata Zaborska of the Institute of Oceanology, PAS, Sopot, Poland for sharing her results related to sediment accumulation rates and depth of sediment mixing data in the Hornsund fjord for sediment cores collected in parallel. We are grateful to Rutger de Wit and an anonymous reviewer for their valuable remarks. We would also like to thank Anna Zamojska of the University of Gdansk for her help in statistical analysis.

\section{References}

Aliani S., Bartholini G., Degl'innocenti F., Delfanti R., Galli C., LAZZONi E., LorenZelli R., Malaguti A., Meloni R., Papucci C., Salvi S. and Zaborska A. 2013. Multidisciplinary investigations in the marine environment of the inner Kongsfjord, Svalbard Islands (September 2000 and 2001). Chemistry and Ecology 20: 19-28.

ANDERSON N.J., BRodersen K.P., RYves D.B., MCGOWAN S., JoHANSSON L.S., JEPPESEN E. and LENG M.J. 2008. Climate versus in- lake processes as controls on the development of community structure in a low- arctic lake (South- West Grenland). Ecosystem 11: 307-324.

ARRIGO K.R., VAN DIJKEN G. and PABI S. 2008. Impact of shrinking Arctic ice cover on marine primary production. Geophysical Research Letters 35: L19063.

BESZCZYŃSKA-MÖLLER A., WĘSŁAWSKI J.M., WALCZOWSKI W. and ZAJĄCZKOWSKI M. 1997. Estimation of glacial meltwater discharge into Svalbard coastal waters. Oceanologia 39: 289-299. 
BIANCHI T.S., DAWSON R. and SAWANGWONG P. 1988. The effects of microbenthic deposit-feeding on the degradation of chloropigments in sandy sediments. Journal of Experimental Marine Biology and Ecology 122: 243-255.

BiAnChi T.S., RolfF C., Widbom B. and ElmGRen R. 2002. Phytoplankton pigments in Baltic Sea seston and sediments: seasonal variability, fluxes, and transformation. Estuarine, Coastal and Shelf Science 55: 369-383.

BIRKEMOE T. and LIENGEN T. 2000. Does collembolan grazing influence nitrogen fixation by cyanobacteria in the high Arctic? Polar Biology 23: 589-592.

Borodina A.V. and LADYGINA L.V. 2013. The effect of cultivation conditions on accumulation of carotenoids in Phaeodactylum tricornutum Bohl. (Bacillariophyta). International Journal of Algae 15: 274-284.

CANUEl E.A., LeRberg E.J., Dickhut R.M., KueHl S.A., BiAnChi T.S. and WAKeHAM S.G. 2009. Changes in sediment and organic carbon accumulation in a highly-disturbed ecosystem: The Sacramento-San Joaquin River Delta (California, USA). Marine Pollution Bulletin 59: 154-163.

ChAPIN D.M., BLISS L.C. and BLEDSOE L.J. 1991. Environmental regulation of nitrogen fixation in a high arctic lowland ecosystem. Canadian Journal of Botany 69: 2744-2755.

Chen N., Bianchi T.S., MckeE B.A. and Bland J.M. 2001. Historical trends of hypoxia on the Louisiana shelf: application of pigments as biomarkers. Organic Geochemistry 32: 543-561.

Cibic T., Blasutto O., Hancke K. and Johnsen G. 2007. Microphytobenthic species composition, pigment concentration, and primary production in sublittoral sediments of the Tronfheimsfjord (Norway). Journal of Phycology 43: 1126-1137.

Cottier F., TVerberg V., Inall M., SVEndsen H., Nilsen F. and Griffiths C. 2005. Water mass modification in an Arctic fjord through cross-shelf exchange: The seasonal hydrography of Kongsfjorden, Svalbard. Journal of Geophysical Research 110: 1-18.

Desphande B.N., TRemblay R., Pienitz R. and VincenT W.F. 2014. Sedimentary pigments as indicators of cyanobacterial dynamics in a hypereutrophic lake. Journal of Paleolimnology 52: 171-184.

DOBRZYN P., TATUR A. and KECK A. 2009. Photosynthetic pigments as indicators of phytoplankton during spring and summer in Adventfjorden (Spitsbergen). Oceanology 49: 368-376.

DreWniK A., WęSŁaWsKi J.M., WŁodARSKa-KowalCZUK M., ŁąCKA M., PromińSKa A., ZABORSKA A. and GŁUCHOWSKA M. 2016. From the worm's point of view: I: Environmental setting of benthic ecosystem in Arctic fjord (Hornsund, Spitsbergen). Polar Biology 39: 1411-1424.

Falk-Petersen S., Dahl T.M., Scott C.L., Sargent J.R., Gulliksen B., Kwaśniewski S., Hop H. and MiLlaR R.-M. 2002. Lipid biomarkers and trophic linkages between ctenophores and copepods in Svalbard waters. Marine Ecology Progress Series 227: 187-194.

FAlK-Petersen S., MAYZAud P., KatTNER G. and SARgEnt J.R. 2009. Lipids and life strategy of Arctic Calanus. Marine Biology Research 5: 18-39.

FIETZ S., NICKLISCH A. and OBERHÄNSLI H. 2007. Phytoplankton response to climate changes in Lake Baikal during the Holocene and Kazantsevo Interglacials assessed from sedimentary pigments. Journal of Paleolimnology 37: 177-203.

Florian C.R., Miller G.H., Fogel M.L., Wolfe A.P., Vinebrooke R.D. and GeisRdottir A. 2015. Algal pigments in Arctic lake sediments record biogeochemical changes due to Holocene climate variability and anthropogenic global change. Journal of Paleolimnology 54: 53-69.

Freiberg R., Nõmm M., Tõnno I., AlliksaAR T., NõGes T. and Kisand A. 2011. Dynamics of phytoplankton pigments in water and surface sediments of a large shallow lake. Estonian Journal of Earth Sciences 60: 91-101.

Gervais M., Atallach E., GyakUm J.R. and Tremblay L.B. 2016. Arctic air masses in a warming world. American Meteorological Society 29: 2359-2373. 
GÖRLICH K., WĘSŁAWSKI J.M. and ZAJĄCZKOWSKI M. 1987. Suspensions settling effect on macrobenthos biomass distribution in the Hornsund fjord, Spitsbergen. Polar Research 5: 175-192.

GRZELAK K. and KotwiCKi L. 2012. Meiofaunal distribution in Hornsund fjord, Spitsbergen. Polar Biology 35: 269-280.

Guilizzoni P., Marchetto A., Lami A., Brauer A., Vigliotti L., Musazzi S., Langone L., MancA M., LuCChini F., CALANChi N., Dinelli E. and Mordenti A. 2006. Records of environmental and climatic changes during the late Holocene from Svalbard: paleolimnology of Kongressvatnet. Journal of Paleolimnology 36: 325-351.

Hegseth E.N. 1992. Sub-ice assemblages of Barents Sea: Species composition, chemical composition and growth rates. Polar Biology 12: 485-496.

ITOH N., TANI Y. and SOMA M. 2003. Sedimentary photosynthetic pigments of algae and phototrophic bacteria in Lake Hamana, Japan: temporal changes of anoxia in its five basins. Limnology 4: $139-148$.

JEFFREY S.W. and VESK M. 1997. Introduction to marine phytoplankton and their pigment signatures. In: S.W. Jeffrey, R.F.C. Mantoura and S.W. Wright (eds) Phytoplankton pigments in oceanography. SCOR UNESCO Publishing, Paris: 37-84.

JEFFREY S.W. and WRIGHT S.W. 1997. Qualitative and quantitative HPLC analysis of SCOR reference algal cultures. In: S.W. Jeffrey, R.F.C. Mantoura and S.W. Wright (eds) Phytoplankton pigments in oceanography. SCOR UNESCO Publishing, Paris: 37-84.

JEFFREY S.W., LLEWELLYN C.A., BARLOW R.G. and MANTOURA R.F.C. 1997. Pigment processes in the sea: a selected bibliography. In: S.W. Jeffrey, R.F.C. Mantoura and S.W. Wright (eds) Phytoplankton pigments in oceanography. SCOR UNESCO Publishing, Paris: 167-178.

JiAnG S., LIU X., SUN J., YUAN L., SUN L. and WANG Y. 2011. A multi-proxy sediment record of late Holocene and recent climate change from lake near Ny-Ålesund, Svalbard. Boreas 40: $468-480$.

JøRGENSEN B.B., GLUD R.N. and Holby O. 2005. Oxygen distribution and bioirrigation in Arctic fjord sediments (Svalbard, Barents Sea). Marine Ecology Progress Series 292: 85-95.

Kay J.E., Holland M.M., Bitz C.M., Blanchard-Wrigglesworth E.A., GetTelman A., CONLEY A. and BAILEY D. 2012. The influence of local feedbacks and northward heat transport on the equilibrium Arctic climate response to increased greenhouse gas forcing. Journal of Climate 25: 5433-5450.

KowalewsKa G., WiTKOWSKI A. and TOMA B. 1996. Chlorophylls c in bottom sediments as markers of diatom biomass in the southern Baltic Sea. Oceanologia 38: 227-249.

Kowalewska G., Winterhalter B., TAlbot H.M., MaXwell J.R. and Konat J. 1999. Chlorins in sediments of the Gotland Deep (Baltic Sea). Oceanologia 41: 81-97.

Krajewska M., SzymCZaK-ŻYŁa M. and KowalewsKa G. 2017. Carotenoid determination in recent marine sediments - practical problems during sample preparation and HPLC analysis. Current Chemistry Letters 6: 91-104.

LEAVITT P.R. and Hodgson D.A. 2001. Sedimentary pigments. In: J.P. Smol, H.J. Birks and W.M. Last (eds) Tracking Environmental Change Using Lake Sediments. Kluwer Academic Publisher, Dordreht: 295-325.

LeavitT P.R., Vinebrooke R.D., Donald D.B., Smol J.P. and SchindleR D.W. 1997. Past ultraviolet radiation environments in lakes derived from fossil pigments. Nature 388: 457-459.

Leu E., Mundy C.J., Assmy P., Campbell K., Gabrielsen T.M., Gosselin M., JuUl-PederSEN T. and GRADINGER R. 2015. Arctic spring awakening - Steering principles behind the phenology of vernal ice algal blooms. Progress in Oceanography 139: 151-170.

LOUdA J.W., Li J., LiU L., WinfREE M.N. and BAKER E.W. 1998. Chlorophyll-a degradation during cellular senescence and death. Organic Geochemistry 29: 1233-1251. 
LOUDA J.W., LIU L. and BAKER E.W. 2002. Senescence- and death-related alternation of chlorophylls and carotenoids in marine phytoplankton. Organic Geochemistry 33: 1635-1653.

MANABE S. and STOUFFER R.F. 1980. Sensitivity of global climate model to an increase of $\mathrm{CO}_{2}$ concentration in the atmosphere. Journal of Geophysical Research 85: 5529-5554.

McGowan S., Barker P., Haworth E.Y., LeAVITT P.R., Maberly S.C. and PATES J. 2012. Humans and climate as drivers of algal community change in Windermere since 1850 . Freshwater Biology 57: 260-277.

MEYERS P.A. 1997. Organic geochemical proxies of paleoceanographic, paleolimnologic, and paleoclimatic processes. Organic Geochemistry 27: 213-250.

MoratA N. and RENAUd P.E. 2008. Sedimentary pigments in the western Barents Sea: A refelction of pelagic- benthic coupling? Deep Sea Research II 55: 2381-2389.

MuCKenHuber S., NilSEN F., Korosov A. and SANDVEn S. 2016. Sea ice cover in Isfjorden and Hornsund, Svalbard (2000-2014) from remote sensing data. The Cryosphere 10: 149-158.

Overpeck J., Hughen K., Hardy D., Bradley R., Case R., Douglas M., Finney B., GajewSki K., Jacoby G., Jennings A., Lamoureux S., Lasca A., Macdonald G., Moore J., Retelle M., SMith S., Wolfe A. and ZielinSKi G. 1997. Arctic Environemntal Change of the Last Four Centuries. Science 278: 1251-1256.

Paerl H.W., Valdes L.M., Pinckney J.L., Piehler M.F., Dyble J. and Moisander P.H. 2003. Phytoplankton photopigments as indicators of estuarine and coastal eutrophication. BioScience 53: 953-964.

Patoine A. and LEAVITT P.R. 2006. Century-long synchrony of fossil algae in a chain of Canadian prairie Lakes. Ecology 87: 1710-1721.

Pettersen R., Johnsen G., Berge J. and KJeldsberg Hovland E. 2011. Phytoplankton chemotaxonomy in waters around the Svalbard archipelago reveals high amounts of $\mathrm{Chl} \mathrm{b}$ and presence of gyroxanthin-diester. Polar Biology 34: 627-635.

Piwosz K., Walkusz W., Hapter R., Wieczorek P., Hop H. and WikToR J. 2009. Comparison of productivity and phytoplankton in a warm (Kongsfjorden) and cold (Hornsund) Spitsbergen fjord in mid-summer 2002. Polar Biology 32: 549-559.

Post E., Forchhammer M.C., Bret-Harte M.S., Callaghan T.V., Christensen T.R., ElBerling B., Fox A.D., Gilg O., Hik D.S., Høye T.T., Ims R.A., JePPeSEN E., Klein D.R., Madsen J., Mcguire A.D., RYsgaArd S., Schindler D.E., Stirling I., TAMSTORF M.P., Tyler N.J.C., VAN DeR Wal R., Welker J., WoOKey P.A., SCHMidt N.M. and AastruP P. 2009. Ecological dynamics across the Arctic associated with recent climate change. Science 325: $1355-1358$.

RASIQ K.T., KURIAN S., KARAPURKAR S.G. and NAQVi S.W.A. 2016. Sedimentary pigments and nature of organic matter within the oxygen minimum zone (OMZ) of the Eastern Arabian Sea (Indian margin). Estuarine, Coastal and Shelf Science 176: 91-101.

REUSS N. and CONLEY D.J. 2005. Effects of sediment storage conditions on pigment analyses. Limnology and Oceanography: Methods 3: 477-487.

Reuss N., CONLEY D.J. and BIANCHI T.S. 2005. Preservation conditions and the use of sediment pigments as a tool for recent ecological reconstruction in four Northern European estuaries. Marine Chemistry 95: 283-302.

SCHÜLlER S.E., Allison M.A., BiAnChI T.S., Tian F. and SAVAGE C. 2013. Historical variability in past phytoplankton abundance and composition in Doubtful Sound, New Zealand. Continental Shelf Research 69: 110-122.

SMOŁA Z.T., TATAREK A., Wiktor J.M., WikTor J.M.W. JR., KubisZYN A. and WęSŁAWSKi J.M. 2017. Primary producers and production in Hornsund and Kongsfjorden-comparison of two fjord system. Polish Polar Research 38: 351-373. 
SteWART K.J., CoXson D. and Grogan P. 2011. Nitrogen inputs by associative cyanobacteria across a low Arctic tundra landscape. Arctic, Antarctic and Alpine Research 43: 267-278.

SWERPEL S. 1985. The Hornsund fiord: water masses. Polish Polar Research 6: 475-496.

SZYMCZAK-ŻYŁA M. and KowALEWSKA G. 2007. Chloropigments a in the Gulf of Gdańsk (Baltic Sea) as markers of the state of this environment. Marine Pollution Bulletin 55: 512-528.

SZYMCZAK-ŻYŁA M. and KowALEWSKA G. 2009. Chloropigments-a in sediments of the Gulf of Gdansk deposited during the last 4000 years as indicators of eutrophication and climate change. Palaeogeography, Palaeoclimatology, Palaeocology 284: 283-294.

SZYMCZAK-ŻYŁA M., WAWRZYNIAK-WYDROWSKA B. and KOWALEWSKA G. 2006. Products of chlorophyll $a$ transformation by selected benthic organisms in the Odra Estuary (Southern Baltic Sea). Hydrobiologia 554: 155-164.

SZYMCZAK-ŻYŁA M., LOUdA J.W. and KowalewsKA G. 2008. Comparison of extraction and HPLC methods for marine sedimentary chloropigment determinations. Journal of Liquid Chromatography and Related Technologies 31: 1162-1180.

SZYMCZAK-ŻYŁA M., KowALEWSKA G. and LOUdA J.W. 2011. Chlorophyll-a and derivatives in recent sediments as indicators of productivity and depositional conditions. Marine Chemistry 125: 39-48.

SZYMCZAK-ŻYŁa M., KrajewsKa M., Winogradow A., ZaborsKa A., BreEdVeld G.D. and KOWALEWSKA G. 2017. Tracking trends in eutrophication based on pigments in recent coastal sediments. Oceanologia 59: 1-17.

Tani Y., Matsumoto G.I., Soma M., Soma Y., Hashimoto S. and KaWai T. 2009. Photosynthetic pigments in sediment core HDP-04 from Lake Hovsgol, Mongolia, and their implication for changes in algal productivity and lake environment for the last $1 \mathrm{Ma}$. Quaternery International 205: 74-83.

Tribovillard N.,Algeo T.J., Lyons T. and Riboulleau A. 2006. Trace metals as paleoredox and paleoproductivity proxies: An uptade. Chemical Geology 232: 12-32.

Wassmann P., DuARTE C.M., Agusti S. and SeJR M.K. 2011. Footprints of climate change in the Arctic marine ecosystem. Global Change Biology 17: 1235-1249.

WELSCHMEYER N.A. and LORENZEN C.J. 1985. Chlorophyll a budgets: Zooplankton grazing and phytoplankton growth in temperate fjord and Central Pacific Gyres. Limnology and Oceanography 30: 1-21.

Weydmann A., Coelho N.C., Serrão E.A., BurzyŃski A. and Pearson G.A. 2016. Pan-Arctic population of the keystone copepoded Calanus glacialis. Polar Biology 39: 2311-2318.

WĘSŁAWSKI J.M. and LEGEŻYŃSKA J. 1998. Glaciers caused zooplankton morality? Journal of Plankton Research 20: 1233-1240.

WęSŁAWSKI J.M., WIKTOR J.JR. and KOTWICKI L. 2010. Increase in biodiversity in the arctic rocky littoral, Sorkappland, Svalbard, after 20 years of climate warming. Marine Biodiversity 40: 123-130.

WIKTOR J. and WOJCIECHOWSKA K. 2005. Differences in taxonomic composition of summer phytoplankton in two fjords of west Spitsbergen, Svalbard. Polish Polar Research 26: 259-268.

WŁodARSKA-KowALCZUK M., PAWŁOWSKA J. and ZAJĄCZKOWSKI M. 2013. Do foraminifera mirror diversity and distribution patterns of microbenthic fauna in an Arctic glacial fjord? Marine Micropaleontology 103: 30-39.

Wold A., Darnis G., Søreide J.E., Leu E., Philippe B., Fortier L., Poulin M., Kattner G., Graeve M. and FAlK-Petersen S. 2011. Life strategy and diet of Calanus glacialis during the winter- spring transition in Amundsen Gulf, south-eastern Beaufort Sea. Polar Biology 34: 1929-1946. 
Wróbel B., Filippini M., PiwowarczyK J., Kędra M., Kuliński K. and Middelboe M. 2013. Low virus to prokaryote ratios in the cold: benthic viruses and prokaryotes in subpolar marine ecosystem (Hornsund, Svalbard). International Microbiology 16: 45-52.

ZABORSKA A. 2017. Sources of ${ }^{137}$ Cs to an Arctic fjord (Hornsund, Svalbard). Journal of Environmental Radioactivity 180: 19-26.

ZABorska A., BeSZCZyŃSKA-MöLler A. and WŁodARsKa-KowalcZuK M. 2017. History of heavy metal accumulation in the Svalbard area: Distribution, origin and transport pathways. Environmental Pollution 231: 437-450.

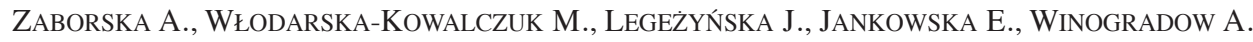
and DEJA K. IN PRESS. Sedimentary organic matter sources, benthic consumption and burial in west Spitsbergen fjords - Signs of maturing of Arctic fjordic system? Journal of Marine System: doi.org/10.1016/j.jmarsys.2016.11.005.

ZAJĄCZKowski M., SzCZuciński W., Plessen B. and Jernas P. 2010. Benthic foraminifera in Hornsund, Svalbard: Implications for paleoenvironmental reconstructions. Polish Polar Research 31: 349-375.

ZAPATA M., JeFFrey S.W., Wright S.W., ROdRiguez F., GARRido J.L. and Clemenston L. 2004. Photosynthetic pigments in 37 species (65 strains) of Haptophyta: implications for oceanography and chemotaxonomy. Marine Ecology Progress Series 270: 83-102.

Received 13 July 2017

Accepted 4 October 2017 